\title{
Pelatihan dan Pendampingan Penelitian Tindakan Kelas bagi Guru SMP Aisyiyah Muhammadiyah 3 Malang
}

\author{
Candra Rahma Wijaya Putra1, Eggy Fajar Andalas', Hudaniah Hudaniah² \\ ${ }^{7}$ Departemen Pendidikan Bahasa Indonesia, Fakultas Keguruan dan Ilmu Pendidikan, ${ }^{2}$ Fakultas Psikologi, Universitas \\ Muhammadiyah Malang, Jl. Raya Tlogomas No.246, Malang, 65145, Indonesia
}

\begin{abstract}
ARTICLE INFO
Received: 2021-01-18

Revised: 2021-03-23

Accepted: 2021-06-20

Keywords:

Classroom action research, Mentoring,

Training

\section{ABSTRACT}

Teachers must be able to increase the standard of their students' education. Various innovations in improving the quality of learning can be done through Classroom Action Research. However, the facts show that the productivity of teachers at SMP 'Aisyiyah Muhammadiyah 3 Malang has not shown a significant development. As part of efforts to improve the quality of student learning in class, many teachers have not been able to implement Classroom Action Research. Therefore, this service seeks to provide classroom action research training assistance to teachers of SMP 'Aisyiyah Muhammadiyah Malang. This service program is carried out in four structured activities, namely sharing, concept expository, training and mentoring, and writing research articles. Through the activities that have been carried out, it was found that the main cause of the absence of the research being conducted was motivation. Through psychological strengthening and intensive mentoring, supported by $a$ strategy to develop worksheet instruments, can provide significant results. Teachers of SMP 'Aisyiyah Muhammadiyah 3 Malang can design and produce classroom action research.

(C)2021 Published by University of Merdeka Malang. This is an open access article distributed under the CC BY-SA 4.0 license

(https://creativecommons.org/licenses/by-sa/4.0/)

How to cite: Putra, C. R. W., Andalas, E. F., \& Hudaniah, H. (2021). Pelatihan dan Pendampingan Penelitian Tindakan Kelas bagi Guru SMP Aisyiyah Muhammadiyah 3 Malang. Abdimas: Jurnal Pengabdian Masyarakat Universitas Merdeka Malang, 6(3), 456-463. https://doi.org/10.26905/abdimas.v6i3.5321
\end{abstract}

\section{PENDAHULUAN}

Peningkatan kualitas pendidikan berjalan lurus dengan perkembangan zaman. Hal ini tentu saja menjadi tuntutan bagi seluruh penyelenggara pendidikan, baik negeri maupun swasta. Sarana dan prasarana menjadi rujukan utama dalam peningkatan kualitas instansi penyelenggara pendidikan dari segi fisik. Dari segi lain, pada ranah sekolah, guru sebagai Sumber Daya Manusia (SDM) menjadi bagian penting dalam menentukan kemajuan pendidikan (Hartini, 2019; Ibda, 2018; Maya, 2017). Artinya, peningkatan kualitas guru menjadi perihal yang tidak dapat dihindarkan. Hal ini tidak lepas dari adanya perubahan sosial. Perubahan sosial ini berimbas pada tuntutan masyarakat atas kompetensi individu (Genlott \& Grönlund, 2013), begitu juga dengan kompetensi guru. 


\section{Pelatihan dan Pendampingan Penelitian Tindakan Kelas bagi Guru SMP Aisyiyah Muhammadiyah 3 Malang Candra Rahma Wijaya Putra, Eggy Fajar Andalas, Hudaniah Hudaniah}

Terdapat beragam cara yang dapat digunakan untuk mengembangkan kompetensi guru. Caracara yang dapat dilakukan, seperti melanjutkan tingkat pendidikan ke jenjang yang lebih tinggi, ikut serta pada forum diskusi ilmiah, pelatihan keterampilan pengajaran, ataupun peningkatan pengetahuan secara faktual. Dengan kata lain, melalui kegiatan ilmiah dan bernilai intelektual inilah peningkatan kualitas guru dapat direalisasikan. Beberapa cara tersebut telah dilakukan. Namun demikian, peningkatan pengetahuan terkait dunia pendidikan dirasa masih kurang. Peningkatan pengetahuan secara faktual ini dapat dicontohkan dengan keaktifan guru dalam menghasilkan penelitian (Fahrurrozi et al., 2020; Junaid \& Baharuddin, 2020; Sanjaya, 2016). Hal ini tidak dapat dipungkiri karena dunia pendidikan terus berkembang. Situasi dan kondisi pasti akan mengalami perbedaan dari generasi ke generasi yang baru (Handayani \& Rukmana, 2020).

Peningkatan pengetahuan melalui kegiatan penelitian yang relevan dengan guru adalah penulisan karya tulis ilmiah. Karya ini dapat berupa penulisan artikel ilmiah, Penelitian Tindakan Kelas (PTK), buku ajar, Lembar Kerja Peserta Didik (LKPD), dan lain sebagainya. Melalui penulisan karya-karya tersebut, guru akan senantiasa berpikir kritis dalam menyelesaikan berbagai persoalan yang dihadapinya dalam pembelajaran. Guru harus mampu mengidentifikasi masalah, mengembangkan pemahaman dan penalaran melalui rangkaian kerja metodologis, menyusun kesimpulan, serta menyiapkan berbagai alternative jawaban atas permasalahan yang dihadapinya (El Soufi \& See, 2019). Hal ini akan berimplikasi pada peningkatan kualitas pembelajaran dan pengajaran (Andrews, 2015). Akan tetapi, realitasnya tidak banyak guru yang mau melakukan bahkan menguasai penulisan ini, khususnya Penelitian Tindakan Kelas (PTK). Padahal, keberadaan PTK yang dilaksanakan oleh guru pada dasarnya merupakan langkah awal dalam peningkatan sekaligus pengembangan pembelajaran (Hanifah, 2014; Wibawa, 2003). Banyak faktor yang menyebabkan minimnya karya ilmiah guru. Selain efektifitas waktu, juga kurangnya referensi perkembangan karya tulis ilmiah, penemuan ide, pengembangan ide, dan penyelesaian tulisan sesuai dengan ketentuan (Dzikrullah et al., 2020; Haris \& Suharli, 2020; Roekhan, 1991; Lubis, 1981).

Atas dasar permasalahan di atas, maka pengabdian ini merupakan kerjasama Fakultas Keguruan dan Ilmu Pendidikan Universitas Muhammadiyah Malang dengan salah satu sekolah yang merupakan bagian dari Amal Usaha Muhammadiyah. Pada kesempatan ini sekolah yang akan bekerjasama adalah SMP 'Aisyiyah Muhammadiyah 3 Malang. Program pengabdian ini dilakukan atas permintaan guru SMP 'Aisyiyah Muhammadiyah 3 Malang. Hal ini berdasarkan fakta bahwa masih minimnya pengetahuan dan keterampilan guru di sekolah ini dalam melakukan Penelitian Tindakan Kelas. Padahal, keberadaan Penelitian Tindakan Kelas bagi institusi pendidikan tidak hanya berkaitan dengan pemenuhan syarat administrasi semata, tetapi dapat menjadi alat bagi peningkatan kualitas pembelajaran siswa di sekolah. Jika hal ini tidak diatasi, berbagai aktivitas pembelajaran dan permasalahan yang terjadi pada pembelajaran tidak akan pernah dapat diselesaikan. Guru juga tidak akan berpikir kritis untuk menemukan inovasiinovasi sebagai bagian dari pengembangan kualitas pembelajaran yang dilakukannya. Karenanya kegiatan pengabdian ini dapat menjadi solusi bagi permasalahan tersebut.

Kegiatan pelatihan Penelitian Tindakan Kelas ini difokuskan pada beberapa hal, yaitu sebagai berikut. Pertama, tuntutan kualitas pembelajaran di kelas semakin tinggi. Dengan demikian perlu adanya peningkatan kemampuan guru dalam mengenali problematika pembelajaran yang dilakukannya dan menemukan solusi atas permasalahan di dalam kelas. Hasil penelitian tersebut hendaknya dipublikasikan 
ABDIMAS: Jurnal Pengabdian Masyarakat Universitas Merdeka Malang Volume 6, No. 3, August 2021: 456-463

kepada peneliti lain melalui mediumjurnal ilmiah. Kedua, untuk peningkatan pengetahuan dan kompetensi guru dalam melakukan Penelitian Tindakan Kelas diperlukan pelatihan metodologi penelitian tindakan kelas bagi guru SMP Aisyiyah Muhammadiyah 3 Malang secara komprehensif. Ketiga, kompetensi guru dalam melakukan penelitian tindakan kelas perlu ditingkatkan, mengingat tuntutan yang harus dipenuhi guru dalam menjalankan profesinya. Keempat, pemberian penjelasan metodologi penelitian tindakan kelas hingga terpublikasi pada jurnal.

Dampak yang ingin dihasilkan dari pelatihan ini adalah: (1) Rasa percaya diri guru semakin meningkat; (2) Menjadi soft skill tambahan bagi guru di bidang penelitian dan penulisan; (3) Dapat menularkan pengalaman/pengetahuannya kepada guru yang lain (instansi lain); (4) Meningkatkan kualitas dan kuantitas membaca secara efektif; (5) Mengenali kemampuan dan potensi diri; (6) Dapat mengorganisasikan gagasan secara sistematis terkait bidang pendidikan; (7) Akan membiasakan berpikir dan berbahasa secara tertib; (8) Memperluas pengetahuan; dan (9) Dapat mengaplikasikan hasil penelitian/gagasan pada kegiatan pembelajaran sehingga kualitas pembelajaran dan peserta didik semakin baik.

\section{METODE}

Kegiatan pengabdian berlokasi di SMP Aisyiyah Muhammadiyah 3 Malang. Sekolah berlokasi di JI. Husni Tamrin No.3, Klojen, Kota Malang, Jawa Timur. Sekolah memiliki status akreditasi B (Baik). Total guru di sekolah sejumlah 15 orang dari berbagai latar bidang keilmuan yang berbeda.

Sebelum kegiatan pengabdian dilaksanakan, dilakukan observasi awal ke sekolah untuk mendapatkan gambaran mengenai kondisi sekolah. Selain itu juga dilakukan wawancara dengan kepala sekolah untuk mendapatkan gambaran mengenai karya-karya yang telah dihasilkan oleh guru. Melalui wawancara tersebut diperoleh gambaran jika guru di sekolah ini masih lemah dalam penelitian dan penulisan karya penelitian, utamanya Penelitian Tindakan Kelas. Untuk memecahkan masalah tersebut dilakukan metode pelaksanaan pengabdian pelatihan dan pendampingan Penelitian Tindakan Kelas sebagai berikut: (1) Sosialisasi program pengabdian melibatkan kepala sekolah, wakil kepala sekolah, dan guru-guru; (2) Penguatan konsep dan metode penulisan Penelitian Tindakan Kelas; dan (3) Pendampingan penulisan artikel Penelitian Tindakan Kelas.

Pertama, sosialisasi program pengabdian dilakukan dengan memberikan penjelasan dan kesamaan persepsi mengenai metode dan jadwal kegiatan untuk disepakati bersama. Aktivitas ini melibatkan pihak sekolah dan tim pengabdi. Kedua, ekspositori konsep yaitu dengan pembekalan berupa wawasan dan penjelasan mengenai penelitian tindakan kelas. Kegiatan ini akan dilakukan melalui kegiatan tatap muka, yaitu sebanyak tiga kali. Pemahaman tentang PTK guru SMP 'Aisyiyah Muhammadiyah 3 Malang dilakukan dengan metode paparan, diskusi, dan tanya jawab. Isi kegiatan ini akan bermuara pada kemampuan menemukan problematika pembelajaran di dalam kelas dan mencari solusinya sebagai topik penulisan artikel ilmiah. Kegiatan mencakup pemaparan materi secara teoretis serta implementasi praktis dalam pelaksanaan Penelitian Tindakan Kelas. Pemaparan materi ini juga didukung dengan penggunaan contoh yang berasal dari artikel jurnal Nasional untuk dibedah satuan-satuan unsur yang ada di dalamnya agar dapat dipahami oleh guru. Selain itu juga dilakukan penguatan konsep-konsep 
mengenai Penelitian Tindakan Kelas melalui materi power point. Ketiga, setelah pemaparan materi dilanjutkan dengan proses penulisan artikel ilmiah. Kegiatan ini akan diisi dengan proses pengembangan topik yang telah diperoleh. Pada kegiatan ini guru akan mulai mengumpulkan data dan menerapkan solusi atas problematika pembelajaran yang ditemuinya. Melalui kegiatan penelitian ini akan dikembangkan menjadi kerangka tulisan sesuai dengan sistematika artikel ilmiah. Seluruh proses ini dilakukan dengan metode asistensi. Asistensi yang dilakukan tidak terbatas pada kegiatan tatap muka, tetapi juga secara daring. Proses pendampingan ini dimaksudkan pada penyelesaian akhir hingga proses publikasi pada jurnal nasional. Kegiatan di atas akan disesuaikan dengan jadwal yang telah diprogram. Secara periodik aktivitas program pelatihan dan pendampingan yang dilakukan dapat dilihat pada tabel 1 berikut.

Tabel 1. Agenda kegiatan pengabdian

\begin{tabular}{|c|c|c|c|}
\hline & Kegiatan & Waktu & Pemateri \\
\hline \multicolumn{2}{|c|}{ Sosialisasi program pengabdian } & 24 Agustus 2020 & $\begin{array}{l}\text { Candra Rahma Wijaya Putra, } \\
\text { M.A., M.Pd }\end{array}$ \\
\hline \multirow[t]{3}{*}{$\begin{array}{l}\text { Penguatan konsep } \\
\text { dan metode PTK }\end{array}$} & $\begin{array}{l}\text { Menjadi Guru yang Baik: Pers- } \\
\text { pektif Psikologi Pendidikan }\end{array}$ & 1 September 2020 & Hudaniah, M.Si \\
\hline & Pentingnya PTK bagi Guru & 7 September 2020 & $\begin{array}{l}\text { Candra Rahma Wijaya Putra, } \\
\text { S.S., S.Pd., M.A }\end{array}$ \\
\hline & $\begin{array}{l}\text { Menulis PTK dalam Bentuk } \\
\text { Artikel Jurnal Ilmiah }\end{array}$ & 14 September 2020 & $\begin{array}{l}\text { Eggy Fajar Andalas, S.S., } \\
\text { M.Hum }\end{array}$ \\
\hline \multirow{2}{*}{$\begin{array}{l}\text { Pendampingan } \\
\text { penulisan artikel } \\
\text { PTK }\end{array}$} & $\begin{array}{l}\text { Perencanaan PTK } \\
\text { Pelaksanaan PTK }\end{array}$ & $\begin{array}{l}8 \text { Oktober } 2020 \\
29 \text { Oktober } 2020\end{array}$ & $\begin{array}{l}\text { Candra Rahma Wijaya Putra, } \\
\text { S.S., S.Pd., M.A }\end{array}$ \\
\hline & Penyelesaian PTK & 13 November 2020 & $\begin{array}{l}\text { Eggy Fajar Andalas, S.S., } \\
\text { M.Hum } \\
\text { Hudaniah, M.Si }\end{array}$ \\
\hline
\end{tabular}

\section{HASIL DAN PEMBAHASAN}

Kegiatan pengabdian ini diawali dengan proses observasi. Tujuan observasi di sini adalah untuk mengidentifikasi permasalahan dan kebutuhan kegiatan pembelajaran yang ada di SMP Aisyiyah Muhammadiyah 3 Malang. Observasi dilakukan dengan cara wawancara langsung dengan kepala sekolah pada bulan Juli hingga Agustus 2020. Metode observasi yang digunakan adalah wawancara dan angket. Dari hasil observasi, pihak sekolah memiliki permasalahan pada produktivitas guru yang memiliki keterkaitan dengan pengembangan pembelajaran di sekolah tersebut. Artinya, dapat dikatakan bahwa kondisi guru-guru sangat minim pengalaman menulis PTK. Hal ini disebabkan karena: (1) Kegiatan guruguru di sekolah yang padat; (2) PTK atau jenis penelitian lainnya tidak menjadi kewajiban bagi guru-guru di sekolah swasta; (3) Rentang kelompok umur guru-guru cukup tinggi; dan (4) Kurangnya motivasi guru dalam melakukan penelitian.

Observasijuga dilakukan dengan menyebarkan angket untuk guru-guru. Angket berisi pertanyaanpertanyaan terkait pengalaman penelitian guru. Dari hasil isian angket, hampir seluruh guru-guru tidak pernah melakukan penelitian. Data observasi tentang kondisi guru-guru tersebut mengarahkan pada salah satu permasalahan mendasar yaitu permasalahan motivasi dan inisiasi guru dalam melaksanakan penelitian tindakan kelas. Penelitian tindakan kelas pada dasarnya dapat meningkatkan kualitas pembelajaran dan sebagai bahan kebutuhan administratif sekolah. 
ABDIMAS: Jurnal Pengabdian Masyarakat Universitas Merdeka Malang Volume 6, No. 3, August 2021: 456-463

Berdasarkan hasil observasi tersebut, maka kegiatan pelatihan dan pendampingan ini memiliki konsep 'pembekalan'. Tahap pertama, berupa kegiatan pembekalan dilaksanakan selama tiga kali pertemuan tatap muka dan sisanya melalui daring, yaitu dimulai pada minggu pertama bulan September. Pembekalan ini diawali dengan materi psikologi pendidikan oleh Ibu Hudaniah, S. Psi., M.Si. Beliau merupakan dosen Psikologi UMM yang merangkap sebagai kepala BK (Bimbingan Konseling) UMM. Tujuan pembekalan ini adalah memotivasi guru untuk mengembangkan diri sekaligus pembelajarannya. Hal ini akan sejalan dengan prestasi sekolah.
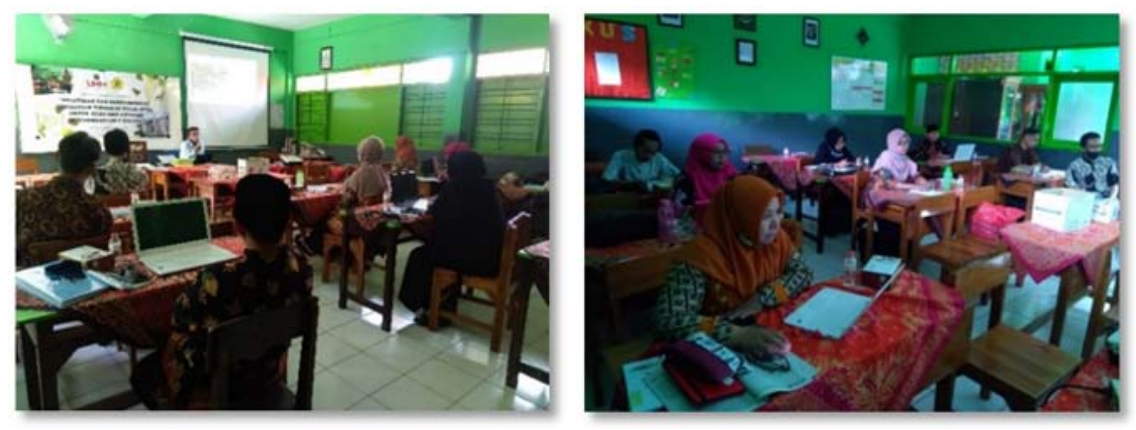

Gambar 1. Pembekalan motivasi psikologi dan materi PTK

Pembekalan selanjutnya adalah tentang pemahaman dasar PTK dan teknis-teknis dalam melakukan PTK. Selain itu juga disampaikan tentang manfaat PTK, baik untuk guru, siswa, maupun instansi sekolah. Materi ini disampaikan oleh Eggy Fajar Andalas, M.Hum. dan Candra Rahma Wijaya Putra, M.A. yang merupakan dosen Pendidikan Bahasa Indonesia di UMM.

Tahap kedua, yaitu pelatihan dan pendampingan dalam melaksanakan PTK. Berdasarkan hasil observasi, maka pengerjaan PTK ini dilasanakan secara berkelompok sesuai dengan bidang keilmuan. Hal ini sebagai antisipasi guru-guru senior yang mengalami kendala dalam teknis penggunaan IT. Kegiatan pelatihan dan pendampingan ini menggunakan bantuan Lembar Kerja (LK) 1. Lembar kerja 1 ini berisi langkah-langkah PTK, termasuk langkah-langkah pengumpulan data. LK ini menjadi pengetahuan sekaligus alat identifikasi awal bagi guru untuk mengumpulkan segala informasi yang diperlukan dalam penelitiannya. Dari 15 guru, terdapat lima kelompok penulisan PTK. Setiap kelompok berisi guru senior dan guru muda sesuai dengan kesamaan bidang studi (keahlian). Hal ini menjadi salah satu solusi mengatasi kesulitan guru senior dalam menggunakan IT.

Tahap ketiga, yaitu proses penulisan merupakan kegiatan memindahkan hasil pengumpulan data dan analisis dalam bentuk karya tulis ilmiah dengan sistematika yang berlaku untuk PTK. Proses penulisan ini dilaksanakan melalui proses pembimbingan dan pendampingan. Pelaksanaannya melalui email dan WA. Proses penulisan ini dibantu dengan Lembar Kerja (LK) 2. Lembar kerja 2 berisi teknis penulisan laporan penelitian dalam bentuk artikel ilmiah.

Dari hasil proses sampai bulan Oktober, terdapat lima judul PTK, antara lain: (1) Meningkatkan pemahaman peserta didik dengan metode pembelajaran peta konsep pada materi zakat di kelas $9 \mathrm{~A}$ 
SMP Aisyiyah Muhammadiyah 3 Kota Malang; (2) Peningkatan keterampilan membaca perintah soal siswa kelas vii; (3) Upaya peningkatan efektivitas pelajaran IPA kelas 8 di SMP Aisyiyah Muhammadiyah 3 Malang dengan model pembelajaran berbasis Penelitian objek alam; (4) Strategi Problem Posing Untuk Meningkatkan Pemahaman Siswa Dalam Membaca Teks Report Pada Siswa Kelas Tiga SMP Muhammadiyah 3 Malang; dan (5) Penerapan metode PBL (Problem Based Learning) untuk meningkatkan keaktifan dan hasil belajar IPA pada siswa SMP Aisyiyah Muhammadiyah 3 Malang kelas VII.

Melalui pelatihan ini tampak peningkatan tidak hanya pada aspek pengetahuan, tetapi juga keterampilan guru dalam merancang, mengindentifikasi, hingga melaksanakan PTK. Penggunaan LK dapat menjadi metode efektif bagi guru dalam mendesain PTK di kemudian hari.

\section{Pembahasan}

Hasil luaran yang diharapkan dari kegiatan program pengabdian ini adalah peningkatan pengetahuan dan keterampilan guru dalam melakukan Penelitian Tindakan Kelas. Dari aktivitas pengabdian yang dilakukan peningkatan tidak hanya dalam pengetahuan, tetapi keterampilan guru dalam merancang hingga melaksanakan Penelitian Tindakan Kelasnya. Hal ini disebabkan peran penggunaan Lembar Kerja sebagai metodeyang efektifbagi guru dalam mengembangkan PTK. Hal ini tampak dari usaha lima kelompok guru yang terdiri dari kombinasi guru senior dan junior telah mempu mengembangkan Penelitian Tindakan Kelas berbasis permasalahan yang dialami guru dalam pembelajaran.

Berdasarkan hasil tersebut, kegiatan ini mampu mengatasi permasalahan kesulitan penulisan Penelitian Tindakan Kelas bagi guru di SMP 'Aisiyah Muhammadiyah 3 Malang. Kegiatan ini memberikan dampak positif kepada mitra. Dampak tersebut dapat dilihat pada tabel berikut.

Tabel 2. Dampak Pelaksanaan Pengabdian

\begin{tabular}{ll}
\hline \multicolumn{1}{c}{ Kegiatan } & \multicolumn{1}{c}{ Dampak bagi Peserta } \\
\hline Sosialisasi program pengabdian & Pendataan problematika penulisan Penelitian Tindakan Kelas guru \\
& Peningkatan pengetahuan konseptual Penelitian Tindakan Kelas \\
& Peningkatan pengetahuan metodologi Penelitian Tindakan kelas \\
Penguatan konsep dan metode PTK & Peningkatan motivasi psikologi sebagai pendidik \\
& $\begin{array}{l}\text { Peningkatan pengetahuan struktur dan komposisi artikel ilmiah hasil } \\
\text { Penelitian Tindakan Kelas }\end{array}$ \\
Pendampingan penulisan artikel PTK & $\begin{array}{l}\text { Pengetahuan standar penulisan artikel ilmiah hasil Penelitian Tindakan } \\
\text { Pelakan Kelas }\end{array}$ \\
\hline
\end{tabular}


ABDIMAS: Jurnal Pengabdian Masyarakat Universitas Merdeka Malang Volume 6, No. 3, August 2021: 456-463

\section{SIMPULAN DAN SARAN}

Kegiatan pengabdian ini bertujuan meningkatan pengetahuan dan keterampilan guru dalam melakukan Penelitian Tindakan Kelas. Dari program kegiatan yang dilakukan, kegiatan ini mampu mengatasi permasalahan kesulitan penulisan Penelitian Tindakan Kelas bagi guru di SMP 'Aisiyah Muhammadiyah 3 Malang. Kegiatan ini tidak hanya meningkatkan pengetahuan guru terhadap Penelitian Tindakan Kelas, tetapi juga meningkatkan keterampilan guru dalam merancang hingga melaksanakan Penelitian Tindakan Kelas. Hal ini utamanya karena bantuan penggunaan Lembar Kerja dan pendampingan intensif yang telah dirancang menjadi langkah kerja bagi aktivitas Penelitian Tindakan Kelas.

Program ini memiliki keterbatasan pada aspek pendanaan. Selain itu motivasi bagi guru sekolah swasta untuk melakukan Penelitian Tindakan Kelas juga kurang. Hal ini karena guru swasta tidak dituntut secara administratif untuk menghasilkan karya ilmiah. Karenanya, perlu adanya kebijakan strategis yang dapat merangsang motivasi guru-guru untuk menulis karya ilmiah. Selain itu, diperlukan pendampingan secara berkelanjutan pada bidang penulisan karya ilmiah lainnya, utamanya bagi guru sekolah swasta, agar dapat meningkatkan kompetensi dan motivasi dalam menghasilkan karya ilmiah.

\section{UCAPAN TERIMA KASIH}

Penulis mengucapkan terima kasih kepada Direktorat Penelitian dan Pengabdian Masyarakat Universitas Muhammadiyah Malang yang telah membiayai program pengabdian ini.

\section{DAFTAR PUSTAKA}

Andrews, R. (2015). Critical thinking and/or argumentation in higher education. The Palgrave Handbook of Critical Thinking in Higher Education, 49-62. https://doi.org/10.1057/9781137378057_3

Dzikrullah, A. A., Fauzan, A., \& Asriny, N. I. (2020). Upaya peningkatan kualitas karya ilmiah guru (studi kasus di lingkungan Mts YAPI Pakem). E-Dimas: Jurnal Pengabdian Kepada Masyarakat, 11(1), 119. https://doi.org/10.26877/e-dimas.v11i1.4163

El Soufi, N., \& See, B. H. (2019). Does explicit teaching of critical thinking improve critical thinking skills of English language learners in higher education? A critical review of causal evidence. Studies in Educational Evaluation, 60, 140-162. https://doi.org/10.1016/j.stueduc.2018.12.006

Fahrurrozi, M., Ibrahim, D. S. M., Aswasulasikin, A., \& Hizbi, T. (2020). Peningkatan penguasaan guru dalam penelitian tindakan kelas melalui diklat KTI. Jurnal Dimaswadi, 1(1), 31-34.

Genlott, A. A., \& Grönlund, Å. (2013). Improving literacy skills through learning reading by writing: The iWTR method presented and tested. Computers \& Education, 67, 98-104.

https://doi.org/10.1016/j.compedu.2013.03.007

Handayani, S. L., \& Rukmana, D. (2020). Peningkatan kemampuan menulis karya ilmiah guru melalui pelatihan penelitian tindakan kelas bagi guru SD. Publikasi Pendidikan: Jurnal Pemikiran, Penelitian dan Pengabdian, 10(1), 8-13. https://doi.org/10.26858/publikan.v10i1.9752

Hanifah, N. (2014). Memahami Penelitian Tindakan Kelas: Teori dan Aplikasinya. UPI Press. 
Pelatihan dan Pendampingan Penelitian Tindakan Kelas bagi Guru SMP Aisyiyah Muhammadiyah 3 Malang Candra Rahma Wijaya Putra, Eggy Fajar Andalas, Hudaniah Hudaniah

Haris, A. H., \& Suharli, S. (2020). Pemetaan kompetensi guru sekolah dasar dalam menyusun artikel hasil penelitian yang layak terbit di jurnal ilmiah. Jurnal Profesi Keguruan, 6(1), 73-77.

Hartini, S. (2019). Kompetensi profesional guru dalam meningkatkan motif berprestasi peserta didik: Studi di SDN Karangpucung 04 dan SDN Karangpucung 05 Kabupaten Cilacap. Indonesian Journal of Education Management \& Administration Review, 3(1), 71-76.

Ibda, H. (2018). Penguatan literasi baru pada guru madrasah ibtidaiyah dalam menjawab tantangan era revolusi industri 4.0. Journal of Research and Thought on Islamic Education (JRTIE), 1(1), 1-21. https://doi.org/10.24260/jrtie.v1i1.1064

Junaid, R., \& Baharuddin, M. R. (2020). Peningkatan kompetensi pedagogik guru melalui PKM Lesson Study. To Maega/ : Jurnal Pengabdian Masyarakat, 3(2), 122-129.

https://doi.org/10.35914/tomaega.v3i2.413

Lubis, M. (1950). Tehnik Mengarang. Balai Pustaka.

Maya, R. (2017). Esensi Guru dalam Visi-Misi Pendidikan Karakter. Edukasi Islami: Jurnal Pendidikan Islam, 2(3).

Roekhan, R. (1991). Menulis Kreatif Dasar-Dasar dan Petunjuk Penerapan. Malang: Yayasan A3.

Sanjaya, D. H. W. (2016). Penelitian Tindakan Kelas. Prenada Media.

Wibawa, B. (2003). Penelitian Tindakan Kelas. Jakarta: Dirjen Dikdasmen. 